\title{
The influence of lidocaine and racemic bupivacaine on neuromuscular blockade produced by rocuronium. A study in rat phrenic nerve-diaphragm preparation ${ }^{1}$
}

\author{
Influência da lidocaína e da bupivacaína racêmica no bloqueio neuromuscular produzido pelo \\ rocurônio. Estudo em preparação nervo frênico-diafragma de rato
}

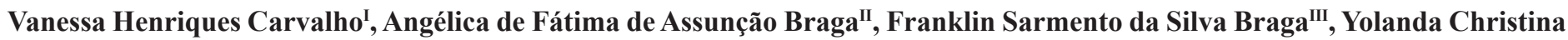 \\ S. Loyola ${ }^{\mathrm{IV}}$, Daniele Ribeiro de Araújov ${ }^{\mathrm{v}}$, Mario Mantovani ${ }^{\mathrm{VI}}$
}

\author{
I Master, Department of Pharmacology, Faculty of Medical Sciences, UNICAMP, Sao Paulo, Brazil.

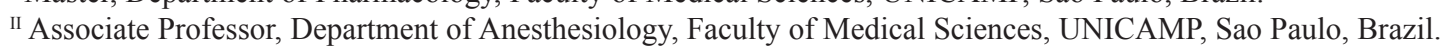 \\ ${ }^{\text {III }} \mathrm{PhD}$, Department of Anesthesiology, Faculty of Medical Sciences, UNICAMP, Sao Paulo, Brazil. \\ ${ }^{\text {IV }} \mathrm{PhD}$, Department of Pharmacology, Faculty of Medical Sciences, UNICAMP, Sao Paulo, Brazil. \\ v PhD, Department of Biochemistry, Institute of Biology, UNICAMP, Sao Paulo, Brazil.

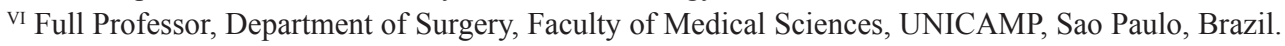

\begin{abstract}
Purpose: To evaluate in vitro lidocaine and racemic bupivacaine effects in neuromuscular transmission and in neuromuscular blockade produced by rocuronium. Methods: Rats were distributed in 5 groups $(n=5)$ in agreement with the studied drugs: lidocaine, racemic bupivacaine, rocuronium, separately (Groups I, II, III); rocuronium in preparations exposed to local anesthetics (Groups IV, V). The concentrations used were: $20 \mu \mathrm{g} / \mathrm{mL}, 5 \mu \mathrm{g} / \mathrm{mL}$ and $4 \mu \mathrm{g} / \mathrm{mL}$, for lidocaine, bupivacaine and rocuronium, respectively. It was evaluated: 1) amplitude of diaphragm muscle response to indirect stimulation, before and 60 minutes after separately addition of lidocaine, racemic bupivacaine and rocuronium and the association of local anesthetics - rocuronium; 2) membrane potentials (MP) and miniature end-plate potentials (MEPP). Results: Lidocaine and bupivacaine separately didn't alter the amplitude of muscle response and MP. In preparations previously exposed to lidocaine and racemic bupivacaine, the rocuronium blockade was significantly larger $(90.10 \pm 9.15 \%$ and $100 \%$, respectively), in relation to the produced by rocuronium separately $(73.12 \pm 9.89 \%)$. Lidocaine caused an increase in the frequency of MEPP, being followed by blockade; racemic bupivacaine produced decrease being followed by blockade. Conclusions: Local anesthetics potentiated the blockade caused by rocuronium. The alterations of MEPP identify presynaptic action.
\end{abstract}

Key words: Anesthetics, Local. Lidocaine. Bupivacaine. Neuromuscular Blocking Agents. Rats.

\section{RESUMO}

Objetivo: Avaliar in vitro os efeitos da lidocaína e bupivacaína racêmica na transmissão neuromuscular e no bloqueio neuromuscular produzido pelo rocurônio. Métodos: Ratos foram distribuídos em 5 grupos $(n=5)$ de acordo com a droga estudada: lidocaina, bupivacaína racêmica, rocurônio, isoladamente (Grupos I, II, III); rocurõnio em preparações expostas aos anestésicos locais (Grupos IV, V). As concentrações utilizadas foram: $20 \mu \mathrm{g} / \mathrm{mL}, 5 \mu \mathrm{g} / \mathrm{mL}$ e $4 \mu \mathrm{g} / \mathrm{mL}$, para lidocaína, bupivacaína e rocurônio, respectivamente. Avaliou-se: 1) amplitude das respostas do músculo diafragma à estimulação indireta, antes e 60 minutos após a adição da lidocaína, bupivacaína racêmica e rocurônio isoladamente e da associação anestésicos locais - rocurônio; 2) potenciais de membrana (PM) e potenciais de placa terminal em miniatura (PPTM). Resultados: A lidocaína e a bupivacaína isoladamente não alteraram a amplitude das respostas musculares e os PM. Nas preparações previamente expostas a lidocaína e a bupivacaína racêmica, o bloqueio com o rocurônio foi significativamente maior $(90,10 \pm 9,15 \%$ e $100 \%$, respectivamente), em relação ao produzido pelo rocurônio isoladamente (73,12 $\pm 9,89 \%)$. A lidocaína causou aumento na freqüência dos PPTM, seguido de bloqueio; a bupivacaína racêmica produziu diminuição seguida de bloqueio. Conclusões: Os anestésicos locais potencializaram o bloqueio causado pelo rocurônio. As alterações do PPTM identificam ação pré-sináptica.

Descritores: Anestésicos Locais. Lidocaína. Bupivacaína. Bloqueadores Neuromusculares. Ratos.

${ }^{1}$ Research performed at Laboratory of Neuromuscular Junction, Department of Pharmacology, Campinas University (UNICAMP), Sao Paulo, Brazil.

\section{Introduction}

There are evidences that pharmacokinetic and pharmacodynamic properties of neuromuscular blocking agents, drugs commonly used in general anesthesia, can be modified by factors as acid-basic state, temperature, monitoring, certain diseases (burns, superior and inferior motor neuron disease) and drugs administered by different routes ${ }^{1-13}$. 
Clinical assays describe that local anesthetics by peridural route, routine used in association to general anesthesia, can interact and potentiate the effects of neuromuscular blocking $\operatorname{agents}^{2-3,7,12}$, interaction also observed in experimental studies ${ }^{9,11}$. However, although these effects have been experimentally demonstrated in isolated preparations and clinical assays, the influence in neuromuscular transmission and in neuromuscular blockade produced by competitive neuromuscular blocking agents it is still objective of little investigation ${ }^{1-3,6-9,11-12,14}$.

In vitro study has for objective to evaluate in rats: the effects of lidocaine and racemic bupivacaine in neuromuscular transmission and its influence in neuromuscular blockade produced by rocuronium.

\section{Methods}

It treats of an experimental in vitro study and the procedures used are in agreement with the Ethical Principles for Animal Research established by Brazilian College for Animal Experimentation (COBEA) and were approved by the Ethics Committee on Animal Institutional Research of the Institute of Biology of the State University of Campinas (protocol $n^{\circ} 1204-1$ ). Were used male rats of Wistar lineage, with weight among $180-250 \mathrm{~g}$. The animals were anesthetized with urethane $(1.2 \mathrm{mg} / \mathrm{kg}$, intraperitonial route) and soon afterwards they were exsanguinated by the section of neck vessels, to facilitate the identification and retreat of left hemidiaphragm with the corresponding phrenic nerves.

The preparation was set up in agreement with the technique described by Bulbring ${ }^{15}$. Hemidiaphragms with the corresponding phrenic nerves were fixed in vat containing $40 \mathrm{~mL}$ of Tyrode nutritious solution with the following composition in $\mathrm{mM}$ : $\mathrm{NaCl} 137 ; \mathrm{KCl} 2.7 ; \mathrm{CaCl}_{2} 1.8 ; \mathrm{NaHCO}_{3} 11.9 ; \mathrm{MgCl}_{2} 0.25 ; \mathrm{NaH}_{2} \mathrm{PO}_{4}$ 0.3 and glucose 11 . The solution was constantly aerated with carbonic mixture $\left(95 \% \mathrm{O}_{2}+5 \% \mathrm{CO}_{2}\right)$ and maintained at $37^{\circ} \mathrm{C}$. The nerve was placed over platinum probes connected to a Grass S48 stimulator. The diaphragm was held by its tendinous portion under constant tension $(5.0 \mathrm{~g})$ through a wire connected to a Load Cell BG50 GMS isometric transducer and submitted to an indirect stimulation frequency of $0.1 \mathrm{~Hz}$ with duration of $0.2 \mathrm{mseg}$. The tension variations produced by diaphragm contractions were recorded by a Gould RS 3400 physiographer. Five groups have been formed $(n=5)$, in agreement with the drug added to the preparation: Group I lidocaine $(20 \mu \mathrm{g} / \mathrm{mL})$; Group II - racemic bupivacaine $(5.0 \mu \mathrm{g} / \mathrm{mL})$; Group III rocuronium $(4 \mu \mathrm{g} / \mathrm{mL})$; Group IV - rocuronium $(4 \mu \mathrm{g} / \mathrm{mL})$ in preparation previously exposed to lidocaine $(20 \mu \mathrm{g} / \mathrm{mL})$; Group V rocuronium ( $4 \mu \mathrm{g} / \mathrm{mL}$ ) in preparation previously exposed to racemic bupivacaine $(5.0 \mu \mathrm{g} /$ $\mathrm{mL}$ ). In the groups IV and $\mathrm{V}$, rocuronium was added to the preparation 30 minutes after the addition of lidocaine and racemic bupivacaine, respectively. The muscle response to indirect stimulation was registered for 60 minutes after drugs addition. It was also used the phrenic nerve-diaphragm preparation for the study of local anesthetics effects in miniature end-plate potentials and in membrane potentials. It was evaluated: 1) the amplitude of diaphragm muscle responses to indirect stimulation, before and 60 minutes after the addition of lidocaine, racemic bupivacaine and rocuronium separately; 2) amplitude of diaphragm muscle responses to indirect stimulation, before and 60 minutes after rocuronium addition in preparations previously exposed to lidocaine and racemic bupivacaine; 3 ) the membrane potentials (MP) and miniature end-plate potentials (MEPP).

\section{Statistical analysis}

The results were expressed in averages and standard deviations. Amplitude of muscle responses was compared before and 60 minutes after drugs administration. To evaluate the reduction of muscle response were used t Student (normal distribution) and Mann-Whitney tests; in the analysis of membrane potential of muscle fibers, Wilcoxon tests were used for paired samples. Significance level of $5 \%$ was assumed $(\alpha=5 \%)$. The power of the test was calculated and it was obtained $\beta>20 \%$ (power $>80 \%$ ). The software used for data analysis was SAS version 8.2.

\section{Results}

Lidocaine and racemic bupivacaine in the studied concentrations and used separately didn't cause reduction in the amplitude of muscle response to indirect electric stimulation in rat phrenic nerve-diaphragm preparation. The blockade produced by rocuronium employed separately was $73.12 \pm 9.89 \%$ (Figure 1). In preparations previously exposed to lidocaine and racemic bupivacaine, the blockade produced by rocuronium was $90.10 \pm$ $9.15 \%$ and $100 \%$, respectively, with significant difference $(\mathrm{p}=0.0037)$ in relation to the produced by rocuronium separately employed. It is observed that the blockade produced by rocuronium in the preparations exposed to bupivacaine was total and it settled more precocious than observed in preparations exposed to lidocaine (Figure 2).

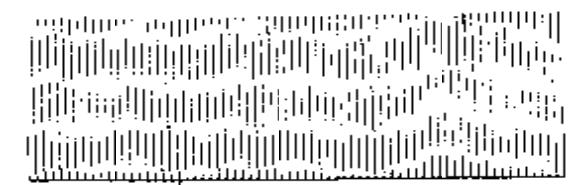

A

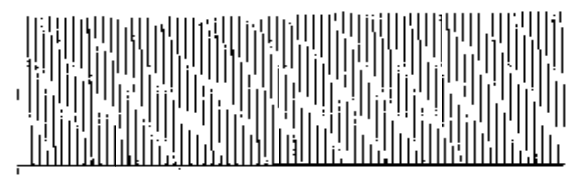

A

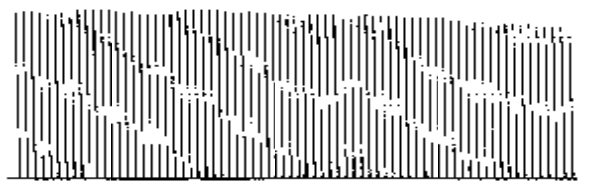

A

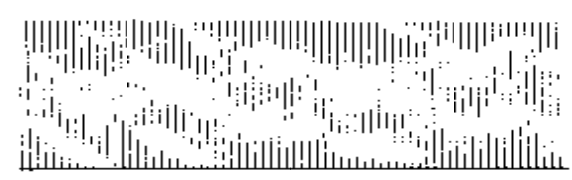

B

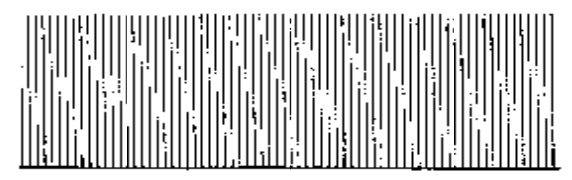

B

FIGURE 1 - Muscle response to indirect stimulation in phrenic nerve-diaphragm preparation. Effects of lidocaine - $20 \mu \mathrm{g} / \mathrm{mL}$ (upper tracing), of racemic bupivacaine - $5.0 \mu \mathrm{g} / \mathrm{mL}$ (middle tracing), of rocuronium - $4.0 \mu \mathrm{g} / \mathrm{mL}$ (lower tracing) in neuromuscular transmission. A: addition of the drug through the preparation; B: 60 minutes after the addition 


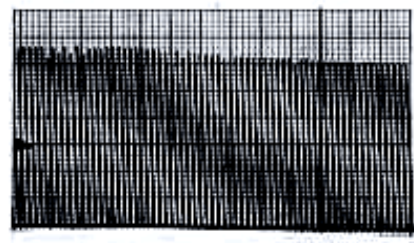

A

A

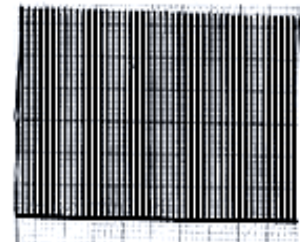

A

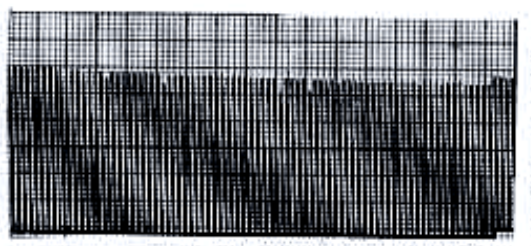

i

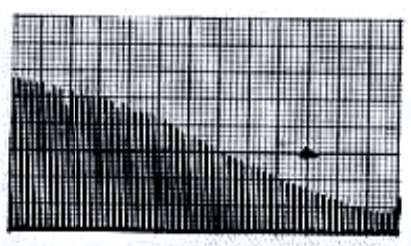

C

FIGURE 2 - Rocuronium effect $(4 \mu \mathrm{g} / \mathrm{mL})$ in the muscle response to indirect stimulation in rat phrenic nerve-diaphragm preparation exposed to lidocaine $-20 \mu \mathrm{g} / \mathrm{mL}$ (upper tracing) and racemic bupivacaine $5.0 \mu \mathrm{g} / \mathrm{mL}$ (lower tracing). A: local anesthetic addition; B: rocuronium addition 30 minutes after local anesthetic; C: 60 minutes after rocuronium. The dart (lower tracing) shows the complete rocuronium blockade $(26.8 \pm 4.32$ minutes $)$

Significant alterations were not observed on membranes potentials. The effects of lidocaine on miniature end-plate potentials (MEPP) were characterized initially by frequency increase, observed 30 minutes after the drug addition, being followed by blockade at 60 minutes. In relation to racemic bupivacaine, it was observed decrease in amplitude and frequency of MEPP, being followed by blockade (Figure 3).

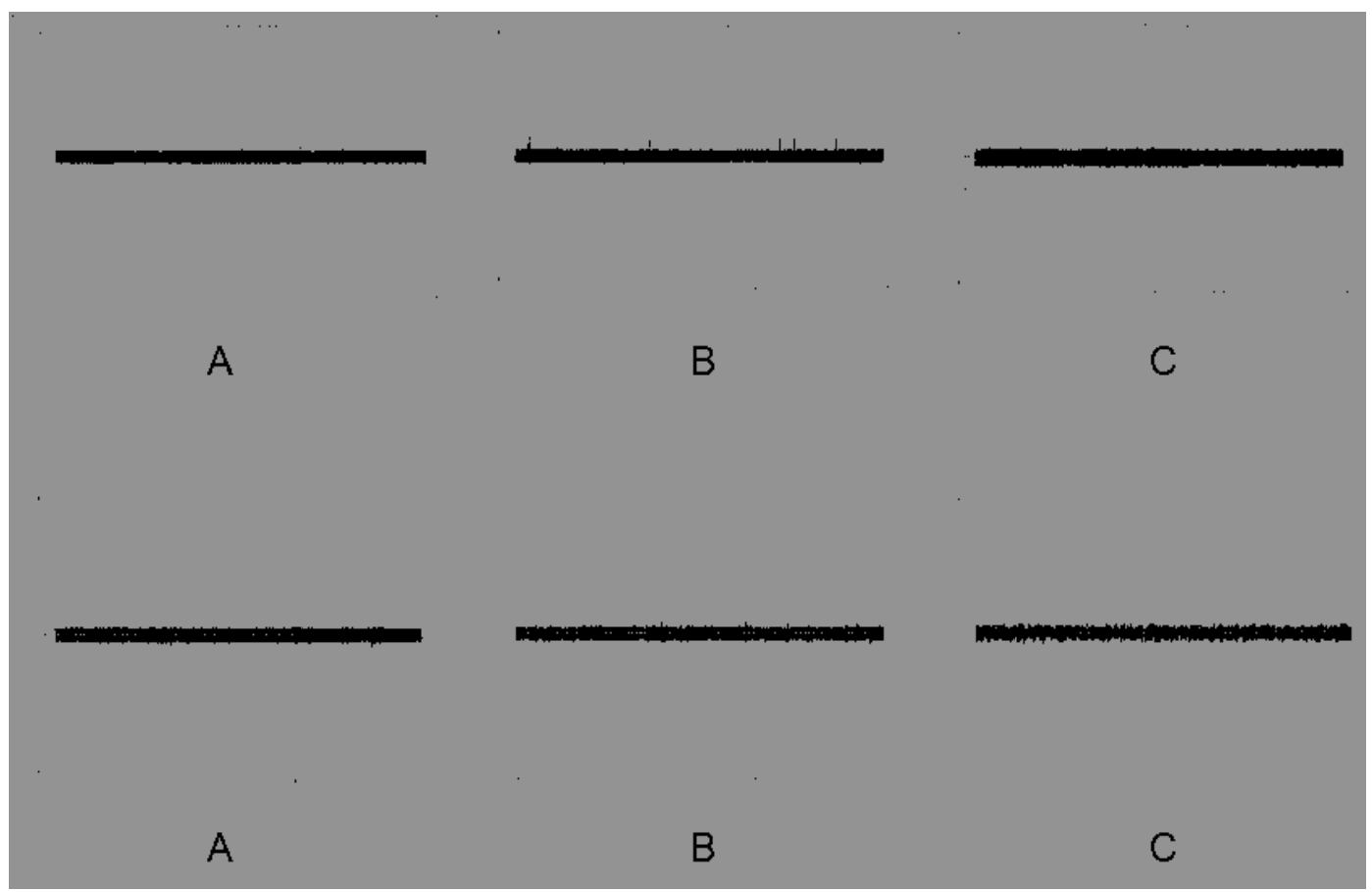

FIGURE 3 - Effect of lidocaine - $20 \mu \mathrm{g} / \mathrm{mL}$ (upper tracing) and racemic bupivacaine - $5.0 \mu \mathrm{g} / \mathrm{mL}$ (lower tracing) in the miniature end-plate potentials (MEPP) in rat phrenic nerve-diaphragm preparation. A: control; B: 30 minutes after the local anesthetic's addition; C: 60 minutes after the local anesthetic's addition 


\section{Discussion}

The interaction between local anesthetics and neuromuscular blocking agents has been described in clinical practice p-3,7-8,12 $^{\text {. }}$ These discoveries are confirmed in experimental works that have as larger advantage, in relation to the clinical researches, the possibility to eliminate the great individual sensibility variability to neuromuscular blocking agents ${ }^{16-17}$.

The results obtained in this work show that in rat phrenic nerve-diaphragm preparation, lidocaine and racemic bupivacaine in the employed concentrations, and, separately administered don't commit neuromuscular transmission, however, the blockade produced by rocuronium in preparations previously exposed to the different local anesthetics was significantly larger than observed in preparations not exposed to local anesthetics.

It was also observed in this study, that in the experiments that racemic bupivacaine was used, the installation of neuromuscular blockade produced by rocuronium was total and it happened more precocious $(26.8 \pm 4.32$ minutes $)$, in relation to the observed in the preparations exposed to lidocaine.

Structure and physiochemical characteristics of racemic bupivacaine can constitute decisive factors for these discoveries, because bupivacaine potency is larger than that of lidocaine. This property can be attributed to its largest hydrophobic behavior indicating an alternative route access to hydrophobic sites in sodium channel protein. The water solubility is an essential characteristic for anesthetic's molecule transport to the nerve fibers, as well as ionization balance that guarantees the existence of ionized and not ionized ways at sites of action. In compensation lipid solubility is also crucial for drug partitioning into the axon, which guarantees that sufficient amount of local anesthetic molecules penetrate in the membrane, inactiving sodium channel. This way the interpretation of the action mechanism, stops having a restricted approach to the importance of the interaction with the lipid or direct, with the sodium channel protein, and becomes including, supplying a more global vision of its action in the cellular membranes ${ }^{18}$.

Additionally local anesthetics as ropivacaine, bupivacaine and mepivacaine, due to their chemical structures, present the property to become membranes fluid, which in association with hydrophobic behavior seems also to influence in its activity ${ }^{19}$. These authors showed that the fluidly promoted by bupivacaine and ropivacaine it is predominantly in the membrane nucleus, in relation to the surface, being more effective with bupivacaine than with ropivacaine. Already with mepivacaine this fluidly was shown homogeneous in both areas of the membrane.

Racemic bupivacaine, ropivacaine and mepivacaine, commonly contains in their piperidinic ring a chiral center, supplying optical isomers with configurations $\mathrm{S}(-)$ and $\mathrm{R}(+)$. Besides the likeness to the receivers, this stereoisomerism is also factor that contributes to the cellular membranes fluidly ${ }^{19}$.

The results of this study resemble each other to the experimental and clinical researches ${ }^{2-3,7-9,11-12,16-17}$ that also demonstrated that local anesthetics employed separately for different routes, don't commit neuromuscular transmission, but they potentiate neuromuscular blockade produced for different neuromuscular blocking.

Matsuo et al. ${ }^{17}$ evaluated in rat phrenic nerve-diaphragm preparation, the action of d-tubocurarine association to different local anesthetics as procaine, lidocaine and etidocaine, and they observed, neuromuscular blocking agents dose-response curve deviation to the left, reflecting increase in the potency of these drugs.
Local anesthetics also had their $\mathrm{ED}_{50}$ reduced for the neuromuscular blocking agents, and the authors concluded that the interaction neuromuscular blocking agents - local anesthetics can be consequent to the true potentied, caused by the action of two types of drugs, in different places of neuromuscular junction.

In clinical studies, the potency and the action duration of different neuromuscular blocking agents, were increased by lidocaine, bupivacaine and mepivacaine used in peridural space, clinically relevant results, and that emphasize the need of frequent monitoring of neuromuscular transmission, when of the use of general anesthesia combined to neuroaxial anesthesia ${ }^{2-3,7,12}$. It is probable that the potency of local anesthetics in neuromuscular junction can differ among the different species and, the extrapolation of these results to man is not quantitatively similar.

In electrophysiological studies, we observed that local anesthetics in the used concentration didn't produce alterations in muscular fibers membrane potential measures, staying above - 82 milivolts, therefore inside of the normality limits, results similar to described for other authors ${ }^{9}$.

In agreement with described by Bowman ${ }^{20}$, it can be inferred that these drugs doesn't possess depolarizing action on muscular fiber, that its action mechanism in the neuromuscular junction is not related to the muscular membrane stability activity, but they impede action potentials spread transport, without affecting the membrane potential.

The experiments accomplished to evaluate the influence of local anesthetics in miniature end-plate potentials (MEPP), evidenced alteration in these potentials. With lidocaine, initially it was verified increase in the frequency of MEPP, what can be attributed to presynaptic action, increasing the neurotransmitter liberation, being followed by blockade. Unlike observed with lidocaine, in preparations exposed to bupivacaine, there was progressive blockade of these, with decrease in the frequency and in the amplitude, until its complete disappearance.

The alterations of miniature end-plate potentials indicate presynaptic action, modifying quantal acetylcholine liberation. The absence of membrane potential alterations demonstrates that in this concentration lidocaine doesn't possess depolarizing action on muscular fiber and that the probable action place is in the neuromuscular junction.

The interaction between local anesthetics and neuromuscular blocking agents it is not completely elucidated, and several mechanisms can be responsible for potentiation observed. Theoretically these agents can interfere in some stage involved in neuromuscular transmission. For presynaptic action, local anesthetics select depress the transport in motor fibers and they reduce acetylcholine liberation during nervous stimulation ${ }^{21-23}$. For postsynaptic action they can link to different specific places of acetylcholine, resulting in receivers' desensitization, besides they could temporarily occlude nicotinic channels receivers ${ }^{24-26}$.

\section{Conclusion}

The lidocaine and bupivacaine separately don't commit neuromuscular transmission, but they potentiate neuromuscular blockade produced by rocuronium. These discoveries turn evident the need of neuromuscular blockade monitoring, and neuromuscular blocking agent's dose reduction when of the simultaneous use of these agents. 


\section{References}

1. Bruckner J, Thomas KC Jr, Bikhazi GB, Foldes FF. Neuromuscular drug interactions of clinical importance. Anesth Analg. 1980;59:678-82. 2. Toft P, Kirkegaard Nielsen H, Severinsen I, Helbo-Hansen HS. Effect of epidurally administered bupivacaíne on atracurium-induced neuromuscular blockade. Acta Anaesthesiol Scand. 1990; 34:649-52.

3. Taivainen T, Meretoja OA, Rosenberg PH. The effect of epidural bupivacaine on vecuronium-induced neuromuscular blockade in children. Acta Anaesthesiol Scand. 1994;38:453-6.

4. Spacek A, Kress HG. Drug interactions with muscle relaxants. Acta Anaesthesiol Scand. 1998;42(Suppl 112):236-8.

5. Haywood PT, Divekar N, Karalliedde LD. Concurrent medication and the neuromuscular junction. Eur J Anaesthesiol. 1999;16:77-91.

6. Nonaka A, Sugawara T, Suzuki S, Masamune T, Kumazawa T. Pretreatment with lidocaine accelerates onset of vecuronium-induced neuromuscular blockade. Masui. 2002;51:880-3.

7. Munakata K, Suzuki T, Watanabe N, Nagai H, Kakishita M, Saeki S, Ogawa S. Influence of epidural lidocaine injection on vecuronium-induced neuromuscular blockade. Masui. 2004;53:1377-80.

8. Cardoso LSM, Martins CR, Tardelli MA. Efeitos da lidocaína por via venosa sobre a farmacodinâmica do rocurônio. Rev Bras Anestesiol. 2005;55:371-80

9. Loyola YCS, Braga AFA, Potério GMB, Sousa SR, Fernandes SCA, Braga FSS. Influência da lidocaína no bloqueio neuromuscular produzido pelo rocurônio. Estudo em preparação nervo frênico-diafragma de rato. Rev Bras Anestesiol. 2006;56:147-56.

10. Braga A De F, Munhoz DC, Braga FS, Araujo DR, Potério GM, Mantovani M. Influence of stimulus frequency on blockade induced by pancuronium and rocuronium: study on rats' phrenic nerve-diaphragm preparation. Acta Cir Bras. 2007;22:446-50.

11. Martins TD, Loyola YCS, Braga AFA. Influência da procainamida sobre o bloqueio neuromuscular produzido pelo rocurônio e investigação sobre o mecanismo de ação da procainamida na junção neuromuscular. Rev Bras Anestesiol. 2007;57:74-82.

12. Suzuki T, Mizutani H, Ishikawa K, Miyake E, Saeki S, Ogawa S. Epidurally administered mepivacaine delays recovery of train-of-four ratio from vecuronium-induced neuromuscular block. Br J Anaesth. 2007;99:721-5.
13. Braga AD, Barcelos CC, Braga FS, Fernandes SC, Franco YO, Mantovani M, Simioni LR. Phenobarbital influence on neuromuscular block produced by rocuronium in rats. Acta Cir Bras. 2008;23:343-7.

14. Ikeda SR, Aronstam RS, Daly JW, Aracava Y, Albuquerque EX. Interactions of bupivacaine with ionic channels of the nicotinic receptor. Electrophysiological and biochemical studies. Mol Pharmacol. 1984;26:293-303.

15. Bulbring E. Observation on the isolated phyrenic nerve-diaphragm preparation of the rat. Br J Pharmacol. 1946;1:38-61.

16. Ellis $\mathrm{CH}$, Wnuck AL, De Beer EJ, Foldes FF. Modifying actions of procaine on the myoneural blocking actions of succinylcholine, decamethonium and d-tubocurarine in dogs and cats. Am J Physiol. 1953;174:277-82. 17. Matsuo S, Rao DB, Chaudry I, Foldes FF. Interaction of muscle relaxants and local anesthetics at the neuromuscular junction. Anesth Analg. 1978;57:580-7.

18. Fraceto LF, De Paula E. Interação de anestésicos locais com lipossomos determinada por espectroscopia de infravermelho. Rev Ciênc Farm Básica Apl. 2006; 27:27-35.

19. Mizogami M, Tsuchiya H, Harada J. Membrane effects of ropivacaine compared with those of bupivacaine and mepivacaine. Fundam Clin Pharmacol. 2002;16:325-30.

20. Bowman WC. Prejunctional and postjunctional cholinoceptors at the neuromuscular junction. Anesth Analg. 1980;59:935-43.

21. Straughan DW. The action of procaine at the neuromuscular junction. J Pharm Pharmacol. 1971;41:94-104.

22. Matthews EK, Quilliam JP. Effects of central depressant drugs upon acetylcholine release. Br J Pharmacol. 1964;22:415-40.

23. Usubiaga JE, Standaert F. The effects of local anesthetics on motor nerve terminals. J Pharmacol Exp Ther. 1968;159:353-61.

24. Sine MS, Taylor P. Local anesthetics and histrionicotoxin are allosteric inhibitors of the acetylcholine receptor. J Biol Chem. 1982;257:8106-14

25. Neher E, Steinback JH. Local anaesthetics transiently block currents through single acetylcholine-receptor channels. J Physiol. 1978;277:153-76.

26. Cohen JB, Boyd ND, Shera NS. Interactions of anesthetics with nicotinic postsynaptic membranes isolated from torpedo electric tissue. In: Fink BR. Molecular mechanisms of anesthesia. Progress in Anesthesiology. New York: Raven Press; 1980. p.165-74.

Conflict of interest: none Financial source: none

\section{Correspondence:}

Angélica de Assunção Braga

R. Luciano Venere Decourt, 245

13084-040 Campinas - SP Brazil

Phone: (55 19)3289-5092

franklinbraga@terra.com.br

\section{How to cite this article}

Carvalho VH, Braga AFA, Braga FSS, Loyola YCS, Araújo DR, Mantovani M. The influence of lidocaine and racemic bupivacaine on neuromuscular blockade produced by rocuronium. A study in rat phrenic nerve-diaphragm preparation. Acta Cir Bras. [serial on the Internet] 2009 May-Jun;24(3). Available from URL: http://www.scielo.br/acb 